\title{
How to Improve Performance?
}

\author{
Sri Langgeng Ratnasari, Gandhi Sutjahjo
}

\begin{abstract}
Employee performance is the most important factor for the organization, because employee performance greatly determines organizational performance, therefore employee performance must be improved. The purpose of this study was to determine the effect of Competence on employee work motivation, Organizational Culture on employee work motivation, Competence and Organizational Culture Employee motivation, Competence on employee Performance, Organizational Culture on Employee Performance, Motivation on Employee Performance, Competence on Employee Performance through Motivation as an intervening variable, Organizational Culture of Employee Performance through Motivation as an intervening variable, Competence and Organizational Culture on Employee Performance, Competence and Organizational Culture on Employee Performance through Motivation as an Intervening Variable. This type of research is descriptive quantitative research. The population of this research is employees of PT. PBI as many as 250 people with a sample of 154 people. PT. PBI one of manufacturing company in Batam City. Data analysis techniques using Structural Equation Modeling. The results of this study are as follows; Effect of Competence on latent variables Motivation has an effect but not significant. Effect of Organizational Culture on Motivation. Competence towards Motivation has no significant effect, Organizational Culture on Motivation has a significant effect. Competence has a significant effect on performance. Organizational culture has no significant effect on performance. Competence, Organizational Culture has no significant effect on performance. Motivation has no significant effect on performance. Competence has a significant effect on employees. Organizational culture has no significant effect on employee performance.
\end{abstract}

Keywords: Competence, Organizational Culture, Employee Performance, Motivation

\section{INTRODUCTION}

PT. PBI is a manufacturing company in Batam City. PT. PBI raises several issues regarding competence, organizational culture and work motivation is still low. This is related after observations and direct interviews in the field some time when the number of employees does not match the competencies of employees and organizations that are less conducive. many are found not achieving work targets given by the company to

Revised Manuscript Received on October15, 2019

* Correspondence Author

Sri Langgeng Ratnasari*, Riau Kepulauan University, Indonesia. Email: sarisucahyo@yahoo.com

Gandhi Sutjahjo, Riau Kepulauan University, Indonesia. Email: gandhi.sucahyo@yahoo.com employees. Therefore it is necessary to conduct research to determine competence, organizational culture, work motivation on employee performance.

Formulation of the problem

1. Does competence affect employee work motivation?

2. Does Organizational Culture affect employee work motivation?

3. Does Organizational Competence and Culture affect employee work motivation?

4. Does competence affect employee performance?

5. Does Organizational Culture affect employee performance?

6. Does work motivation affect employee performance?

7. Does competence affect employee performance through motivation as an intervening variable?

8. Does Organizational Culture affect Employee Performance through Motivation as an intervening variable?

9. Does Organizational Competence and Culture affect Employee Performance?

10. Does Organizational Competence and Culture affect Employee Performance through Motivation as Intervening Variables?

\section{A. Competence}

The notion of competence is the ability to carry out work or tasks based on skills and knowledge and is supported by work attitudes determined by work, then it is said that self-concept is one's attitude, values or self-image [1]. Departing from some understanding, it can be concluded that competence is something inherent in a person, namely work skills, knowledge and behavior that can be used to predict employee performance levels. Something in question can involve motives, self-concept, nature, knowledge or ability or expertise.

\section{B. Organizational Culture}

Organizational culture is what employees perceive and how that perception creates a pattern of beliefs, values and expectations. Schein et.al., defines culture as a pattern of basic assumptions created, discovered, or developed by certain groups when learning to deal with problems of external adaptation and internal integration that have been running well enough to be considered valid, therefore, to be taught to new members as the correct way to perceive, think and feel in connection with the problems they face [2].

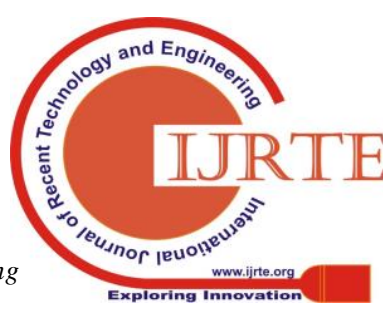


Culture is a set of interactions from the habitual characteristics of members of a group that influence their behavior [3]. Organizational culture is a set of shared values, beliefs and norms that influence the way employees to think, feel, and behave in the workplace [4].

\section{Motivation}

Maslow's theory of needs was developed by Maslow in 1935. Maslow examined that human motivation originates from within a person and cannot be forced, this theory emphasizes that humans are motivated to make an effort, to satisfy the five insatiable needs inherent in human beings themselves .

Motivation is a provision of driving force or driving force given by the leader to encourage employees to work optimally to meet the demands of the work given to them to achieve organizational goals by meeting the needs and giving rewards to employees. work motivation is also an activity that results in, channeling, maintaining, and encouraging a person's behavior to perform certain actions or actions optimally to achieve what the organization targets.

Motivation illustrates the relationship between expectation and purpose, in addition, the relationship between supervisors and underlings [5].

\section{Employee Performance}

What is meant by performance is concrete, measurable and observable work results. An effective performance management system is a process that helps an organization to achieve its long-term and short-term goals, by helping managers and employees do their jobs in a better way. Employee performance is a term such as output, efficiency and effectiveness often associated with productivity [6]. Employee performance will be the level of effectiveness of an organization or performance. The higher the work effectiveness, the higher the performance [7].

\section{METHODOLOGY/MATERIALS}

\section{A. Research Variable}

research variables are attributes or properties or aspects of people or objects that have certain variations that are determined by researchers to be studied and conclusions drawn [8]. In this study the variables are divided into independent variables, namely influencing variables, consisting of Competence and Organizational Culture. The other variable is the dependent variable which is the variable that is affected or which is due to the independent variables. In this study the intervening variable is work motivation, and the dependent variable is Employee Performance.

\section{B. Population}

Population is a collection of all objects to be measured. Population is a generalization area consisting of objects or subjects that have certain qualities and characteristics determined by researchers to be studied and then drawn conclusions. The population in this study are 250 permanent employees of PT. PBI.

\section{Sample}

The sample is part of the number and characteristics possessed by the population [8]. In this study, the sample size is adjusted to the analysis model used, namely the Structural Equation Modeling. In this regard, the sample size for SEM using the maximum likelihood estimation (MLE) estimation model is 100-200 Ghozali samples (2009), or as much as 5-10 times the number of parameters estimated. In this research, the population is the employees of PT. PBI of 154 employees, the amount of which is calculated based on the Slovin formula, this is in accordance with what is explained by Umar the sample needed if the population size is known [9].

\section{RESULT AND FINDING}

\section{A. Test Validity and Reliability}

Test Validity questionnaire conducted to determine the ability of a list of questions to measure what should be measured. The list of questions used in the study is not yet known the level of validity and reliability. For this reason, the validity of each question and the reliability of the list of questions used in this study was tested. A measuring instrument that is not reliable or invalid will provide inaccurate information about the state of the subject or individual subjected to the test. If the wrong information is consciously or unconsciously used as a basis for consideration in making conclusions and decisions, then surely the conclusions and decisions will not be the right conclusions and decisions.

Validity testing criteria is to compare the $r$ count with $r$ table, at a significant level of $95 \%$ or $\alpha=5 \%$. According to Sugiyono, the question item is called valid if the question item has rcount $>r=$ standard $=0.30$ [8]. In this case, what is meant is calculated for each question item, the product moment correlation coefficient between the scores of each item with the total score of all items denoted by Corrected Item Total Correlation in the SPSS program calculation results for each question of a variable. To test the reliability of a list of questions from a research variable the Cronbach's Alpha coefficient is used. The magnitude of the Cronbach's Alpha coefficient indicates the level of reliability of the questionnaire. According to Nugroho (2010) a variable construct is said to be reliable if it has a Cronbach's> value of 0.60 . Calculation of product moment correlation and Cronbach's Alpha coefficient is done with SPSS for

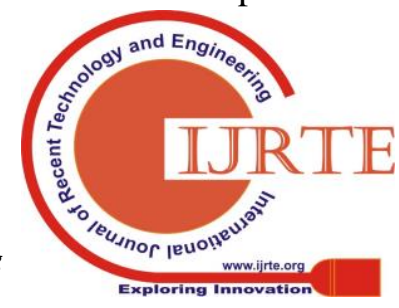


Windows version 22.0 specifically on the Scale sub menu on the Analyze menu. After testing the validity and reliability of all items valid and reliable.

\section{B. Discussion}

For the evaluation of normality, a skwenees test and a kurtosis test were performed. Skweness test is used to see the skewness or skewness of data dissemination, while kurtosis is to see the data distribution spreading. According to Suharyadi (2003), data has a skewed distribution when the critical value (c.r.) for skweness is greater than \pm 3.00 . Data is said to have a sharp spread if the critical value (c.r.) for kurtosis> 3.00. According to Ferdinand (2006) data can be stated to spread normally if the critical value (c.r) for skweness or kurtosis is not greater than \pm 2.58 . In this study criteria were used according to Suharyadi, (2008).

Normality test is performed on the data of each indicator of latent variables, namely variable data on Artifacts, Cultural Values, Cultural Assumptions, Efficiency and Effectiveness. Based on the results of the Confirmatory Factor Analysis (CFA) process of the Amos Version 20.0 for Windows program, the research data for each latent variable obtained from the processing of assessment of normality in Amos Version 22.0 obtained normal results.

Based on the results of testing the data, all latent variable indicators have a standardized estimate (regression weight) in the form of a loading factor or lamda $(\lambda \mathrm{i})>0.50$ and a critical value of C.R $>2,000$ and have a probability smaller than $0.05(* * *)$.

Then it can be said that all indicators of these latent variables are valid or significant.

\section{Analysis of Structural Equation Models}

Model testing is performed using regression coefficients for the variables Competency, Organizational Culture, Motivation and Employee Performance through the output table from the sub menu view or set.

\section{Goodness of Fit Analysis}

Based on the test criteria, Chi-square $(\chi 2)$, Relative Chi-square ( $\chi 2$ / df), RMSEA, GFI, AGFI, TLI, and CFI above and the Goodness of Fit values of Amos for windows version 22 .

\section{E. Analysis of Measurement Models with Determination}

Measurement Model Analysis with the coefficient Effect of Competence, Organizational Culture on Motivation. Effect of Competence, Organizational Culture, and Motivation on Employee Performance. Analysis of the measurement model with determination is used to determine the contribution of exogenous variables to endogenous variables. For this analysis Square Multiple Correlation is used. The amount of
Square Multiple Correlation can be seen in the following Table 1 .

Table 1 Analysis of measurement models Squared Multiple Correlations: (Group number 1 Default model)

\begin{tabular}{ll}
\hline & Estimate \\
\hline MOT &, 229 \\
$\mathrm{P}$ &, 394 \\
\hline
\end{tabular}

Effect of Competence on Motivation has a standardized estimate of 0.221 with $\mathrm{Cr}$ of 1.485 on probability $=0.138$. CR value of $1.485<2.00$ and Probability $=0.138>0.05$ indicates that the effect of Competence on Motivation is positive but not significant.

The influence of Organizational Culture on Motivation has a standardized estimate of 0.288 with $\mathrm{Cr}$ of 2.721 on probability $=0.007$. CR value of 2.721$\rangle$ 2.00 and Probability $=0.007<0.05$ indicates that the influence of Organizational Culture on Motivation is positive and significant.

The influence of Competence on Motivation is positive but not significant, the influence of Organizational Culture on Motivation is positive and significant, then the simultaneous influence of Competence, Organizational Culture on Motivation is positive and significant.

Effect of Competence on latent variables Performance has a standardized estimate of 0.471 with $\mathrm{Cr}$ of 3.254 on probability $=0.001$. CR value $3.254>$ 2.00 and Probability $=0.001<0.05$ indicates that the effect of Competence on Performance is significantly positive.

The influence of Organizational Culture on Employee Performance has a standardized estimate of 0.111 with $\mathrm{Cr}$ of 0.821 on probability $=0.412$. $\mathrm{CR}$ value $=0.821<2.00$ and Probability $=0.412>0.05$ shows that the influence of Organizational Culture on Performance is positive but not significant. This result is not inline with previous studies [10-13].

The influence of Competence on Performance is significantly positive, the influence of latent variables Organizational Culture on Performance is positive but not significant, it can be stated that the effect of Competency and Organizational Culture together on Performance is significantly positive. This result is inline with a previous study [14].

Effect of Motivation on Performance has a standardized estimate (regression weight) of 0.125 with $\mathrm{Cr}$ of 1.472 on probability $=0.141$. $\mathrm{CR}$ value $=1.472$ $<2.00$ and Probability $=0.141>0.05$ shows that the influence of latent variables Motivation on latent variables Performance is positive but not significant. 
The influence of Competence on Performance is significantly positive, the effect of Motivation on Performance is positive but not significant, it can be stated that the effect of Competency and Motivation together on latent variables Performance is significantly positive.

The influence of Organizational Culture on Motivation is positive but not significant, the effect of latent variables Motivation on Performance is not significant positive then it can be stated that the influence of Organizational Culture and Motivation together on Performance is positive but not significant.

The influence of Competence on Performance is significantly positive, The influence of Organizational Culture on Performance is positive but not significant, the effect of Motivation on Performance is not significantly positive then it can be stated the effect of Competence, Organizational Culture and Motivation together on Performance is positive but not significant.

\section{CONCLUSION}

Based on the results of this study can be concluded as follows:

1. Effect of Competence on latent variables Motivation has an effect but not significant.

2. Effect of Organizational Culture on Motivation.

3. Competence towards Motivation has no significant effect.

4. Organizational Culture on Motivation has a significant effect.

5. Competence has a significant effect on performance.

6. Organizational culture has no significant effect on performance.

7. Competence, Organizational Culture has no significant effect on performance.

8. Motivation has no significant effect on performance.

9. Competence has a significant effect on employees.

10. Organizational culture has no significant effect on employee performance.

\section{REFERENCES}

1. Wibowo, 2014. Manajemen Kinerja. Edisi ke-Empat. Jakarta: PT. Raja Grafindo Persada.

2. Schein, E.H., 2014. Organizational Culture and Relationship. San Fransisco: Jossey-Bass Inc.

3. Luthans, F. (2016). Organizational Behavior (Vivin Andhika Yuwono (trans.), Shekar Purwanti, Th. Arie P, and Winong Rosari). Yogyakarta: Andi.

4. Agwu, M.O. (2014). Organizational Culture And Employees Performance In The National. Agency for Food and Drugs Administration and Control (NAFDAC) Nigeria. Global

Journal of Management and Business Research, Volume 14(2), pp. 1-9.

5. Zainun, B. (2014). Management and Motivation. Jakarta: Balai Literature.

6. Gomes, F. C. (2008). Human Resource Management (translation). Yogyakarta: Andi Offset.

7. Daft, R. L. (2014). Organization Theory and Design. Thomson South-Western.

8. Sugiyono, 2015. Metode Penelitian Bisnis. Bandung: CV. Alfabeta,

9. Umar Husein, 2008. Perilaku dan Manajemen Organisasi. Jakarta: Erlangga.

10. Allard, I.N. (2010), Examining Relationship between Organizational Culture and Performance: Moderators of Culture Gap, Northcentral University, Prescott Valley, Arizona.

11. Aripin, Salim, U., Setiawan, M. and Djumahir (2013), "Implications of organizational culture and leadership styles: the effects on job satisfaction and organizational performance of police sector in Bandung, Cimahi, Garut-west java”, IOSR Journal of Business and Management, Vol. 7 No. 5, pp. 44-49.

12. Ratnasari, Sri Langgeng., et al. 2018. Lecturer's Performance: Leadership, Organizational Culture, Work Motvation, and Work Behavior. The 2018 International Conference of Organizational Innovation.

13. Ratnasari, Sri Langgeng., Gandhi Sutjahjo, and Adam. 2018. Impact of Organizational Culture and Organizational Commitment to Employee Performance Through Job Satisfaction in Digital Era. Advances in Economics, Business and Management Research. Volume 64.

14. Ratnasari, Sri Langgeng. Gandhi Sutjahjo, and Adam. 2019. The Contribution Of Competence, Motivation, And Creativity Towards Teacher's Performance Through Work Satisfaction. International Journal of Engineering and Advanced Technology (IJEAT). ISSN: 2249-8958, Volume-8 Issues-5C, May 2019.

\section{AUTHORS PROFILE}

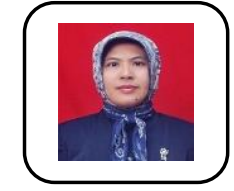

Sri Langgeng Ratnasari is lecturer. She is Doctor of Management from Universitas Airlangga, Indonesia. Her research area in Human Resources Management and Organizational

Behavior 
Gandhi Sutjahjo is lecturer. He is Master of Information System from STMIK Putera Batam, Indonesia. His research area in Information System, Human Resources Management, and Organizational Behavior. 